\title{
Clinical usage of honey as a wound dressing: an update
}

\author{
Honey is an ancient treatment that is increasingly earning its place in modern \\ wound care. Evidence suggests it compares with other dressings in terms of its \\ antibacterial properties, ease of use and ability to promote a moist environment
}

infection; antibacterial; anti-inflammatory; skin grafts

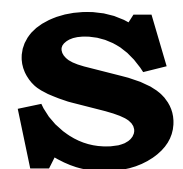

ince Molan last covered this topic in Journal of Wound Care, ${ }^{1}$ there have been advances in the selection of honey for use in wound care, based on its antibacterial properties, and in clinical protocols for its use. This paper examines wound-healing results achieved with honey in the past five years, the extent of its use and practical issues relating to its clinical use.

\section{Use of selected honey}

The potency of honey's antibacterial activity can vary up to a hundred-fold. ${ }^{2}$ Honey's antibacterial activity is partly due to the high osmolarity created by its sugar content, although this reduces as it is diluted by exudate. Honey with no antibacterial activity beyond its osmolarity ceases to be effective against Staphylococcus aureus when diluted with three or four times its volume of exudate. ${ }^{3}$ However, honey produced specifically for wound care can still be inhibitory if diluted to 45-60 times its volume.

Honey's antimicrobial activity is also due to:

Hydrogen peroxide, which is formed in a

'slow-release' manner by the glucose oxidase

added by bees during its production

Phytochemicals from the nectar of particular plant species.

Both activities can vary from sample to sample. In manuka honey (Leptospermum scoparium) and honey from some other Leptospermum species the phytochemical activity can be high, with a broad spectrum of antimicrobial activity. (This activity, the Unique Manuka Factor, is rated as the UMF number on honeys on sale.)

Honey with a median level of hydrogen-peroxide activity and manuka honey with a median level of phytochemical activity are equally as potent as antibacterial agents in vitro, ${ }^{4}$ although manuka honey is

about twice as effective against enterococci. ${ }^{5}$

In wound care the catalase in serum and tissues decomposes to some extent the hydrogen peroxide produced by many honeys, whereas the phytochemical component of Leptospermum honey maintains its activity. Also, the glucose oxidase which produces the hydrogen peroxide in honey only becomes active when honey is diluted, and its acidity is neutralised by exudate. In contrast, the phytochemical factor in Leptospermum honey is active in full-strength honey, giving a more potent antibacterial action that diffuses into the depth of infected tissues, making it the honey chosen for sale for wound care.

\section{Dressing protocols}

The progressive dilution of honey by exudate, together with the absorption of its components into the blood stream, means its osmotic and antiseptic effects last for only two to three days. ${ }^{6}$ Other practical issues that need to be considered when using honey as a wound dressing are described below.

\section{The osmotic effect}

Honey creates a moist environment by drawing exudate to the wound surface, creating a non-adherent interface between the dressing and wound bed. Lawrence $^{6}$ suggested that penetrative osmosis may damage wound tissue, but this does not happen as the underlying circulation provides a flow of replacement fluid. ${ }^{7}$ However, osmotic withdrawal of fluid does prevent maceration of periwound skin.

\section{Dealing with exudate}

Wound exudate can dilute a honey's antibacterial activity, or wash it away, so honey is best soaked into a dressing and covered with a secondary dressing, rather than applied directly to the wound.

Due to its anti-inflammatory action, placing sufficient honey on the wound will decrease the level of exudate. ${ }^{8}$ Until this decrease occurs, frequent dressing changes may be needed on exuding wounds if the honey is being washed away. A new dressing,9 comprising honey gelled with sodium alginate, forms a rubbery sheet similar to a hydrocolloid. This swells into a softer gel as it readily absorbs exudate, keeping honey in contact with the wound bed while preventing the lateral spread of exudate. A honey hydrogel product (L-Mesitran Hydro, Triticum) can
P. C. Molan, Bsc, PhD, Professor, Director of the Honey Research Unit, Department of Biological Sciences, University of Waikato, Hamilton, New Zealand; J.A. Betts, RN, AdDipN, PGDipHsc, MN (Candidate), Nurse Practitioner Wound Care, Health Waikato, Hamilton, New Zealand.

Email: pmolan@waikato. ac.nz

\section{References}

I Molan, P.C. The role of honey in the management of wounds.) Wound Care 1999; 8: 8, 415-418.

2 Molan, P.C.The

antibacterial activity of honey:

2,Yariation in the potency of the antibacterial activity. Bee World 1992; 73:2, 59-76.

3 Cooper, R.A., Molan, P.C. Harding, K.G,Antibacterial activity of honey against strains of Staphylococcus aureus from infected

wounds. J R Soc Med 1999; 92:6, 283-285,

4 Molan, P.C. Honey as a topical antibacterial agent for treatment of infected wounds.World Wide

Wounds 2001 (www. woridwidewounds. com/2001/november/ Molan/honey.as-topicalagenthtml).

5 Cooper, R.A., Molan, P.C., Harding, K.G. Honey and Gram positive cocci of clinical significance in wounds. J Appl Microbiol 2002; 93: 857-863. 6 Lawrence, J.C. Honey and wound bacteria (editorial). J Wound Care 1999:8:4,155. 111 ${ }^{\circ}$ 
Table I. Examples of honey dressings that have achieved successful results after other treatments failed

\begin{tabular}{|c|c|c|}
\hline Wound & Outcome & Reference \\
\hline $\begin{array}{l}\text { Porous non-adherent dressing } \\
\text { placed between graft and } \\
\text { honey dressing }\end{array}$ & $\begin{array}{l}\text { Pseudomonas eliminated; } \\
\text { donor sites healed faster; } \\
\text { better cosmetic results }\end{array}$ & $\begin{array}{l}\text { Robson et al. }{ }^{48} \\
\text { Robson }^{49}\end{array}$ \\
\hline $\begin{array}{l}\text { 36-month-old surgical wound } \\
\text { in the axilla }\end{array}$ & Healed in I month & Cooper et al. ${ }^{30}$ \\
\hline $\begin{array}{l}\text { Skin lesions infected with } \\
\text { Pseudomonas, Staphylococcus } \\
\text { aureus and Enterococcus }\end{array}$ & Healed within 10 weeks & Dunford et al. ${ }^{31}$ \\
\hline $\begin{array}{l}\text { Skin-graft failure of lower leg } \\
\text { cavity wound; infected with } \\
\text { Pseudomonas, Staphylococcus } \\
\text { aureus and MRSA: donor-site } \\
\text { infection }\end{array}$ & $\begin{array}{l}\text { Healed in } 8 \text { weeks: } \\
\text { elimination of wound odour }\end{array}$ & Dunford et al. ${ }^{28}$ \\
\hline $\begin{array}{l}\text { Hydroxyurea-induced leg ulcer } \\
\text { infected with MRSA treated } \\
\text { with UMFI } 2 \text { manuka honey } \\
\text { under DuoDERM (ConvaTec) }\end{array}$ & $\begin{array}{l}\text { Infection cleared in } 14 \\
\text { days; healed in } 21 \text { days }\end{array}$ & Natarajan et al. ${ }^{50}$ \\
\hline
\end{tabular}

\begin{tabular}{|c|c|c|}
\hline $\begin{array}{l}4 \times 4 \mathrm{~cm} \text { non-healing traumatic } \\
\text { wound }\end{array}$ & $\begin{array}{l}\text { Granulation and } \\
\text { epithelialisation visible } \\
\text { within I week; complete } \\
\text { healing in } 6 \text { weeks }\end{array}$ & Dunford et $\mathrm{al}^{28}$ \\
\hline $\begin{array}{l}\text { Ulcer from back of knee to } \\
\text { ankle, infected with } \\
\text { Streptococcus pyogenes and } \\
\text { Staphylococcus aureus treated } \\
\text { with Medihoney }\end{array}$ & $\begin{array}{l}\text { Elimination of odour; } \\
\text { reduction in pain; reduced } \\
\text { bleeding at dressing } \\
\text { change; } 80 \% \text { reduction in } \\
\text { size in } 15 \text { weeks }\end{array}$ & Stewart $^{32}$ \\
\hline $\begin{array}{l}\text { Bilateral leg ulcers, extending } \\
18 \mathrm{~cm} \text { up from ankle on the } \\
\text { inner and outer surfaces of an } \\
88 \text {-year-old patient, treated with } \\
\text { Medihoney }\end{array}$ & Healed in 6 weeks & Richards ${ }^{33}$ \\
\hline $\begin{array}{l}\text { Chronic leg ulcers ( } 20 \text { years), } \\
\text { Medihoney compared with } \\
\text { Aquacel }\end{array}$ & $\begin{array}{l}\text { Cleaner wound bed; } \\
\text { infection and exudate } \\
\text { cleared in } 10 \text { days }\end{array}$ & $\begin{array}{l}\text { Alcaraz and } \\
\text { Kelly }^{45}\end{array}$ \\
\hline $\begin{array}{l}\text { 25-year history of venous } \\
\text { ulceration and recurrent } \\
\text { infection treated with } \\
\text { UMF I0+ manuka honey }\end{array}$ & $\begin{array}{l}\text { Rapid removal of odour; } \\
\text { eczema cleared after } 10 \\
\text { days, but infection } \\
\text { returned under } \\
\text { compression and } \\
\text { NA dressing (johnson } \\
\text { \& Johnson) }\end{array}$ & Kingsley ${ }^{51}$ \\
\hline $\begin{array}{l}14 \text { cases of gangrene in the } \\
\text { genitals and perineum. Honey } \\
\text { was applied directly to the } \\
\text { wounds, which were covered } \\
\text { with a honey-soaked compress }\end{array}$ & $\begin{array}{l}\text { Average debridement time: } \\
5.2 \text { days; granulation: } 9.4 \\
\text { days; healing: } 28.7 \text { days }\end{array}$ & Anoukoum et al. ${ }^{24}$ \\
\hline $\begin{array}{l}\text { Fournier's gangrene, post } \\
\text { surgical debridement }\end{array}$ & Healing in six patients & Gurdal et al. ${ }^{25}$ \\
\hline
\end{tabular}

\section{Results observed in clinical practice}

In our clinical experience a variety of chronic, acute, infected or heavily colonised wounds that did not respond to 'normal management' have been treated with honey. Successful healing was achieved in all patients except those with arterial insufficiency. However, the latter wounds remained free from infection and did not deteriorate further. Varicose ulcers usually healed within three months, including cases where compression could not be used. No patients required systemic antibiotics. As a result, community nurses in our region use honey as the standard treatment for leg ulcers infected or heavily colonised with Pseudomonas.

The most notable results have concerned honey's rapid (within 24 hours) cleansing and deodorising action, particularly on fungating (malignant) wounds. Honey also reduces inflammation and exudate levels, and may suppress the growth of tumour cells, as observed in experimental animals. 10,11

The following randomised controlled trials of honey have demonstrated successful outcomes, when compared with other dressing regimens:

-Honey versus povidone-iodine on central vein catheter exit sites of patients on dialysisn -Honey versus hydrocolloid on split-thickness skin graft donor sites"

- Honey versus phenytoin on chronic leg ulcers 14 - Honey versus povidone-iodine with $70 \%$ ethanol washes on severe postoperative wound infections. ${ }^{15}$

Table 1 gives examples of case reports where honey proved successful after other treatments failed. Many used honey dressings we developed - Combine (Smith \& Nephew) dressing pads impregnated with $25-35 \mathrm{~g}$ of UMF12 or UMF13 manuka honey.

\section{Honey with unspecified antibacterial activity}

The possibility that some honeys may give poor results because they have a low level of antibacterial activity was demonstrated in a prospective randomised controlled trial comparing honey with early tangential excision followed by autologous skin grafting for the treatment of burns. ${ }^{16}$ Honey did not provide as good infection control as early tangential excision, although skin grafting was required in only 11 of the group treated with honey $(n=25)$.

However, in other clinical trials, the author achieved good infection control with the same dressing regimen. ${ }^{17-22}$ For example, a prospective randomised controlled trial ${ }^{17}$ compared Jambhul (Syzygium cumini) honey with silver suiphadiazine in two groups of 50 patients. (One sixth of the total burn area was full-thickness.) In the honey group the 44 positive swabs recorded at baseline reduced 
to four after seven days, compared with 42 positive swabs at baseline and 42 after seven days in the silver-sulphadiazine group. Use of honey was associated with a significantly faster rate of healing. Four of the honey-treated wounds required grafting compared with 11 treated with silver sulphadiazine.

Some cases ${ }^{15,23-27}$ in Table 1 also used honey with unspecified antibacterial activity. Good results were reported in most of these, but the three cases (out of a total of 60) in the trial of Mediprof HoneySoft dressing in which there was infection or failure to heal may be a reflection of the fact that this honey does not have a standardised antibacterial activity.

\section{Pain and honey dressings}

There have been a few reports of honey causing pain when applied to wounds. ${ }^{14,23,28}$ In one study the patient experienced pain for the first 20-30 minutes. ${ }^{28}$ In another case moderate pain occurred for 15-30 minutes. ${ }^{29}$ We have observed that pain is experienced only in very inflamed wounds and disappears once the inflammation has resolved. But there are many reports of honey relieving pain. . $3,15,17,30-33^{2}$

The pain experienced does not seem to be associated with damage to the wound. But there is evidence that honey stimulates nociceptors. ${ }^{34}$ Interestingly, patients have reported a 'peppery' sensation when honey is applied to ulcers. ${ }^{14}$ It is possible, therefore, that in some patients the nerve endings are sensitised and thus more responsive to the honey's acidity and/or its organic chemicals.

\section{Acceptance by the medical profession}

In 2000 an answer to a reader's question in Journal of Wound Care 35 commented that 'honey appears to be becoming popular for the management of infected wounds'. This has become even more the case, reflecting the search for alternatives to antibiotics and the increasing awareness of honey's effectiveness.

Although systematic reviews have concluded that there is a low level of evidence to support the use of honey on chronic wounds, ${ }^{36-38}$ they have not acknowledged that in many published case reports it was only used after standard treatments failed (Most of the randomised controlled trials on honey have been on acute wounds.)

Following increasing evidence from laboratory-based research of honey's antimicrobial properties and from clinical experience of its ability to promote healing, editorial comments in medical journals are now changing from being disparaging ${ }^{39-41}$ to accepting. ${ }^{35,42,43}$

\section{Honeys produced specifically for wound care}

There are over 500 reports of case studies and clinical trials where honey intended as a food product has been used as a wound dressing, and none have
Table I (continued). Examples of honey dressings that have achieved successful results after other treatments failed

\begin{tabular}{|c|c|c|}
\hline Wound & Outcome & Reference \\
\hline $\begin{array}{l}\text { Retrospective review of } 50 \\
\text { cases of lactational breast } \\
\text { abscesses incised, drained and } \\
\text { packed daily with honey- }\end{array}$ & Good response & Efem $^{26}$ \\
\hline $\begin{array}{l}\text { Skin excoriation due to } \\
\text { ostomy bag leakage }\end{array}$ & Rapid epithelialisation & Aminu et al. ${ }^{27}$ \\
\hline $\begin{array}{l}\text { soaked ribbon gauze } \\
16 \text { acute traumatic, } 23 \\
\text { complicated surgical and } \\
21 \text { chronic non-responding } \\
\text { wounds treated with } \\
\text { HoneySoft (Mediprof) }\end{array}$ & $\begin{array}{l}\text { two wounds did not } \\
\text { heal but did not worsen. } \\
\text { Others healed in a mean } \\
\text { time of } 3 \text { weeks (range: } \\
1-28 \text { weeks) }\end{array}$ & Ahmed et $\mathrm{al}^{23}$ \\
\hline
\end{tabular}

reported any adverse effects. ${ }^{8}$ However, clinicians are reluctant to use non-sterile products on open wounds, and it is unlikely the bacterial content of raw honey would meet regulatory requirements for wound-management products. Although raw honey does not contain disease-causing vegetative bacteria (unless recently contaminated), it can contain viable bacterial spores, including Clostridium species ${ }^{44}$

Several commercially available honey items produced specifically for wound care have been approved by the regulatory authorities:

- Australia, Canada and EU member states - a honey ointment (L-Mesitran, Triticum) comprises honey and Medilan, sunflower oil, cod liver oil, aloe vera, calendula, vitamins $\mathrm{A}, \mathrm{C}$ and $\mathrm{E}$ and zinc oxide; L-Mesitran Hydro (Triticum), a hydrogel dressing that contains $30 \%$ honey and is also available as an island dressing (L-Mesitran Border) or incorporated into an open-weave polyester net (L-Mesitran Net). The Triticum products are made from honey of unspecified origin and antibacterial activity

- Australia and all EU member states - Medihoney Antibacterial Wound Gel, Medihoney Antibacterial Honey Barrier (Medihoney, Australia) and (in Australia) Woundcare 18+ (Comvita Medical, New Zealand). These honeys are harvested from Leptospermum species, and their standardised antibacterial activity stems from the unidentified phytochemical antibacterial component derived from Leptosper mum. Medihoney is funded for use in hospitals in Queensland and New South Wales, Australia

- All EU member states - Activon Tulle (Advancis) a triple layer of low-adherent knitted viscose primary dressing BP Type 1 impregnated with honey, and Algivon dressing (Advancis), a honey-impregnated mechanically bonded calcium alginate (M type) fibre dressing. Both are made from Leptospermum honey with standardised antibacterial activity. Activon Tulle is available on the Drug Tariff in the UK
7 Chirife, J., Scarrnato, G., Herszage, L Scientific basis for use of granulated sugar in treatment of infected wounds. Lancet 1982;1: 560-561.

B Molan, P.C. Reintroducing honey In the management of wounds and ulcers: theory and practice. OstomyNVound Manage 2002; 48:11, 28-40.

9 Molan, P.C. Medical dressings comprising gelled honey. European Patent EP 1237561, 2002

10 Swellam,T, Miyanaga, N., Onozawa, M. et al. Antineoplastic activity of honey in an experimental bladder cancer implantation model: in vivo and in vitro studies. Int $J$ Urol 2003; 10: 4,213-219. $11 \mathrm{HamzaOglu}, \mathrm{I}$. Saribeyoglu, K., Durak, H. et al. Protective covering of surgical wounds with honey impedes tumor implantation.Arch Surg 2000; 135:12, 1414-1417.

12 Mutjaba Quadri, K.H. Topical honey versus standard povidone-iodine in the prevention of catheter-related sepsis.) Am Soc Nephrol 1998; 9 : 180A-18IA.

13 Misirlioglu,A., Erog1u, S., Karacaoglan, N. et al. Use of honey as an adjunct in the healing of split-thickness skin graft donor site. Dermatol Surg 2003; 29; 2, 168-172. 


\section{Box I. Key issues for practice}

- Australia, New Zealand and all EU member states --Apinate dressing (Comvita Medical, New Zealand), a honey-impregnated mechanically bonded calcium alginate ( $\mathrm{M}$ type) fibre dressing made from Leptospermum honey with standardised antibacterial activity a - All EU member states - HoneySoft dressings (Mediprof) are pads of polyethylenevinylacetate fibre impregnated with honey of unspecified origin and antibacterial activity. HoneySoft is reimbursed in the Netherlands, in Belgium for trauma patients, in burn centres in England that have their own budgets, and in Greece.

The use of honey-impregnated dressings, honey ointments and honey gel dressings have overcome comments that honey is messy to use and difficult to keep in place. $6,45,46$

\section{Conclusion}

In 1999 an editorial in Advances in Wound Care commented that there is a 'tremendous opportunity to re-examine old treatments and apply them in the current environment'. ${ }^{47}$ Honey, the most ancient of

14 Oluwatosin

Olabanji, Oluwatosin,

$O$.A. et al.A comparison of topical honey and

phenycoin in the treatment of chronic leg

ulcers.Afr J Med Sci 2000;

29:1,31-34.

15 Al-Waili, N.S., Saloom,

K.Y. Effects of topical honey on post-operative wound

infections due to Gram

positive and Gram

negative bacteria

following Caesarean

s e ctions and

hysterectomies. Eur J Med

Res 1999; 4: 126-130.

16 Subrahmanyam, M.

Early tangential excision

and skin grafting of

moderate burns is superior

to honey dressing: a

prospective randomised

trial, Burns 1999; 25: 8

729-73।

17 Subrahmanyam, M.,

Sahapure,A.G., Nagane,

N.S. et al. Effects of topical application of honey on burn wound healing.Ann Burns Fire Disasters 2001; XIV: $3,143-145$

18 Subrahmanyam, M.A prospective randomised clinical and histological study of superficial burn wound healing with honey and silver sulfadiazine. Burns 1998; 24:2, 157- 16 I.

19 Subrahmanyam, $M$. Honey dressing versus boiled potato peel in the treatment of burns: a prospective randomized

study. Burns 1996; 22: 6 ,

491-493.

20 Subrahmanyam, $M$. Honey-impregnated gauze

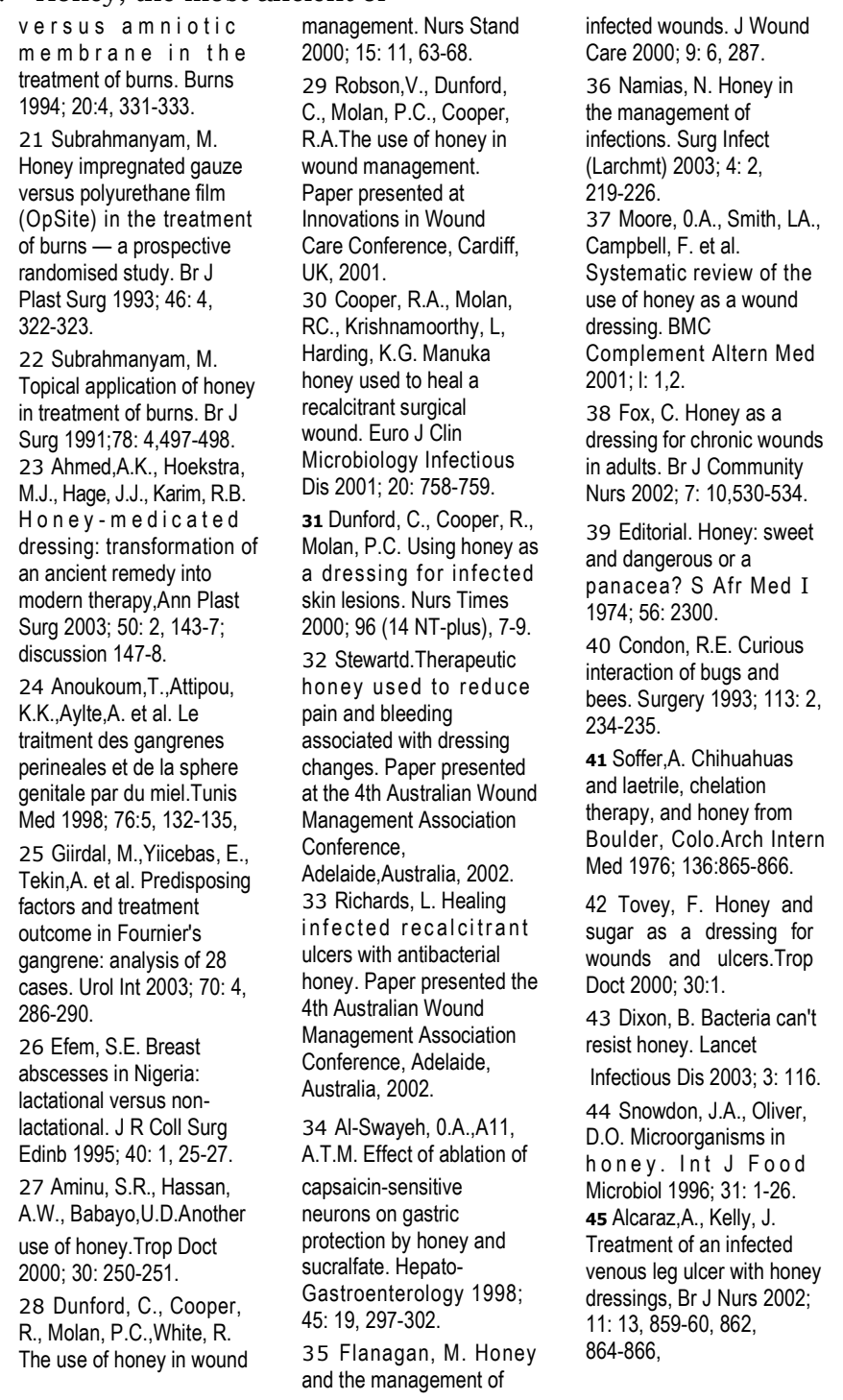

Potency of honeys' antibacterial activity can be variable - use honey with standardised antibacterial activity

Only use products licensed for wound care as they have been finely filtered and sterilised by gamma-irradiation to kill spores

Ensure sufficient honey remains In contact with the wound bed by using absorbent dressings impregnated with honey, or honey gel dressings. Fill any cavities with honey

Ensure the dressings cover any areas of inflammation surrounding the wound. Due to honey's high osmolarity, there is no risk of skin maceration

Change dressings often enough to prevent the exudate washing the honey out of the dressing

wound treatments, is taking its in place in modern wound care. Like modern wound dressings, it is easy to apply, painless and comfortable, harmless to tissues, creates a moist healing environment, is antibacterial and stimulates healing and epithelialisation. ${ }^{8}$
46 Lusby, RE., Coombes, A. Wilinson, J.M. Honey: potent agent for wound healing? J Wound Ostomy Continence Nurs 2002 29: 6, 295-300.

47 Salcido, $R$

Complementary and alternative medicine in wound healing.Adv Wound Care 1999; 12:9, 438. 48 Robson,V.,Ward, R.G., Molan, P.C.The use of honey in split skin grafting Paper presented at the 10th Conference of the European Wound Management Association Harrogate, UK, 2000. 49 Robson, V. University Hospital Aintree, Liverpool, UK. Personal communication, 2000. 50 Natarajan, S., Williamson, D., Grey, J. et al. Healing of an MRSA. colonized, hydroxyu reainduced leg ulcer with honey .J Dermatol Treatment 2001; I 2:33-36. 51 Kingsley,A.The use of honey in the treatment of infected wounds: case studies. Br J Nurs 2001; 10:22 (Tissue Viability Supplement): S 13-520. 